\title{
Compliance with Recommended Practices for Management of Controlled Substances in a Health Care Facility and Corrective Actions
}

\author{
Manon Videau, Suzanne Atkinson, Maxime Thibault, Denis Lebel, and Jean-François Bussières
}

\begin{abstract}
Background: Pharmacists are required to maintain a secure inventory of medications and to ensure proper, safe, and diversion-free dispensing practices.

Objectives: The primary objectives of this study were to determine compliance with recommended practices for the management of controlled substances in a mother-child teaching hospital and to identify actions to improve compliance. The secondary objective was to identify steps in the drug pathway for controlled substances and associated failure modes in the study hospital.
\end{abstract}

Methods: This descriptive cross-sectional study used a framework developed by the California Hospital Association (CHA) to assess compliance with recommended practices for the management of controlled substances in hospitals. For each criterion, a research assistant observed practices within the pharmacy, on patient care units, at outpatient care clinics, and in operating and delivery rooms. The level of compliance was recorded as compliant, partially compliant, or noncompliant. An Ishikawa diagram was developed to illustrate steps in the drug pathway and associated failure modes related to the use of controlled substances in the study hospital.

Results: The pathway for controlled substances at the study hospital was compliant for 56 (49.6\%) of the 113 CHA criteria, partially compliant for $27(23.9 \%)$ of the criteria, and noncompliant for $24(21.2 \%)$ of the criteria; the remaining $6(5.3 \%)$ criteria were not applicable. This practice evaluation highlighted 22 corrective actions, $12(55 \%)$ that could be implemented in the short term, $8(36 \%)$ suitable for implementation in the medium term, and $2(9 \%)$ suitable for both the short and medium term. A total of 57 potential failure modes related to the use of controlled substances were identified.

Conclusions: The pathway for controlled substances at the study hospital was compliant with almost half of the CHA criteria, and 22 corrective actions were identified. Pharmacists, physicians, and nurses should be mobilized to optimize the use of controlled substances throughout the drug-use process.

Keywords: controlled substances, practice guidelines, management audit, drug diversion

\section{RÉSUMÉ}

Contexte: Les pharmaciens sont responsables de maintenir à jour les réserves de médicaments et doivent faire en sorte que les pratiques de distribution soient adéquates, sûres et exemptes de détournement.

Objectifs : Les objectifs principaux de la présente étude consistaient à déterminer le degré de conformité aux pratiques de gestion des substances contrôlées, recommandées dans un hôpital universitaire mère-enfant, et de trouver des mesures pour améliorer leur degré de conformité. L’objectif secondaire visait à recenser les étapes que suivent les substances contrôlées dans le circuit des médicaments et les modes de défaillance qui y sont associés dans l'hôpital à l'étude.

Méthodes : La présente étude descriptive et transversale s'appuyait sur un cadre mis au point par la California Hospital Association (CHA), qui sert à évaluer le degré de conformité aux recommandations relatives aux pratiques de gestion des substances contrôlées dans les hôpitaux. Pour chaque critère, un assistant de recherche observait les pratiques dans le service de pharmacie, les unités de soins, les cliniques de consultation externe et les salles d'opération ou les salles d'accouchement. Il évaluait le degré de conformité à l'aide d'un des qualificatifs suivants : conforme, partiellement conforme ou non conforme. Un diagramme d'Ishikawa a été conçu pour illustrer les étapes du circuit des médicaments et les modes de défaillance associés à l'utilisation de substances contrôlées dans l'hôpital à l'étude.

Résultats : Le circuit des substances contrôlées à l'hôpital où se déroulait l'étude était conforme à $56(49,6 \%)$ des 113 critères de la CHA, partiellement conforme à $27(23,9 \%)$ critères et non conforme à $24(21,2 \%)$ critères; les $6(5,3 \%)$ critères restants n'étaient pas applicables. Cette évaluation des pratiques a mis en évidence 22 actions correctives, dont $12(55 \%)$ pouvaient être mises en place à court terme, $8(36 \%)$ à moyen terme et $2(9 \%)$ à court ou à moyen terme. Les investigateurs ont repéré 57 modes de défaillance potentiels liés à l'utilisation de substances contrôlées.

Conclusions : L'analyse du circuit des substances contrôlées à l'hôpital où se déroulait l'étude a révélé que près de la moitié des critères de la $\mathrm{CHA}$ étaient conformes, et 22 actions correctives ont été proposées. Les pharmaciens, médecins et infirmières devraient participer à l'optimisation 


\section{Can J Hosp Pharm. 2019;72(3):175-84}

de l'utilisation des substances contrôlées dans l'ensemble du processus de distribution des médicaments.

Mots clés : substances contrôlées, guide de pratique, audit opérationnel, détournement de médicaments

\section{INTRODUCTION}

tealing controlled substances is difficult in health care settings. Prescribing, dispensing, and administering such substances rely on a structured process that involves numerous professionals and witnesses, policies and procedures, tools and technologies. Each year, doctors, nurses, and pharmacists who try to divert controlled substances face the dire consequences of their attempts, including fines, disciplinary discharge, or temporary or permanent suspension from work. ${ }^{1}$ Although this system is highly effective, clinical staff and administrators must be proactive in preventing diversion, especially as the health care landscape evolves through automation.

Under the Convention on Psychotropic Substances of 1971, which was adopted at the United Nations Conference for the Adoption of a Protocol on Psychotropic Substances, signatory countries undertake to put in place, by means of their own legislation, a system of international controls on psychotropic substances. ${ }^{2}$ This convention responds to "the diversification and expansion of the spectrum of drugs of abuse and [introduces] controls over a number of synthetic drugs according to their abuse potential on the one hand and their therapeutic value on the other." 2

In Canada, the Controlled Drugs and Substances Act, passed in 1996, provides a legal framework for the distribution and sale of controlled substances. ${ }^{3}$ Several sets of regulations fall under this legislation, including the Narcotic Control Regulations, ${ }^{4}$ the Benzodiazepines and Other Targeted Substances Regulations, ${ }^{5}$ and the Precursor Control Regulations. ${ }^{6}$ For the purposes of this article, we use the term "controlled substances" to describe narcotics, including opioids, controlled drugs, and benzodiazepines dispensed by community and hospital pharmacies. These substances are described in Schedules I to V of the legislation.

Under this legal framework, Canadian pharmacists are required to maintain a secure medication inventory and to ensure proper, safe, and diversion-free dispensing practices. In addition, the legal framework for each province includes provisions requiring that pharmacists maintain adequate control of controlled substances; for example, statement 3.5 of the Standards of Practice of the Ordre des pharmaciens du Québec (the college of pharmacists for the province of Quebec) states that the pharmacist puts in place control mechanisms to prevent diversions. ${ }^{7}$
However, some legally dispensed doses may be diverted, either by health care professionals or by patients, to illegal distribution channels (e.g., the black market) ${ }^{8}$ In addition, illegal controlled substances (e.g., heroin, carfentanyl) may enter the Canadian market through various channels, including e-commerce or illegal importation by transport of goods or by humans. The availability of legal and illegal controlled substances contributes to misuse, addiction, and overdose.

Canada and the United States are among the top users of opioids per capita, and consumption in these countries continues to increase, even while pain remains poorly managed for some patients. ${ }^{910}$ Currently, the main challenge is to effectively combat misuse and diversion while maintaining access to effective pain management. According to the International Narcotics Control Board of the United Nations, the average dose of morphine consumed per capita in 2015 was $117.7 \mathrm{mg}$ in Canada but only $61.0 \mathrm{mg}$ in the United States, $32.2 \mathrm{mg}$ in Australia, $22.8 \mathrm{mg}$ in the United Kingdom, and 27.6 mg in France. ${ }^{11}$ These utilization rates are notably influenced by the availability of various commercial forms, but also by the prescription of these substances to patients. As such, physicians and pharmacists contribute to the availability of these substances for patient care.

According to the government of Canada, the country is facing a national opioid crisis: "The growing number of overdoses and deaths caused by opioids, including fentanyl, is a public health emergency. This is a complex health and social issue that needs a response that is comprehensive, collaborative, compassionate and evidence-based." 12 The Canadian Institute for Health Information has provided evidence of the crisis, reporting that a total of " 21.3 million prescriptions for opioids were dispensed in 2017, compared with 21.7 million in 2016. This is the first decline in overall prescription numbers between 2012 and 2017." ${ }^{13}$ Despite this decrease in prescriptions, O'Connor and others ${ }^{14}$ reported that opioid poisonings resulted in an average of 16 hospitalizations a day in $2016 / 17$, a $53 \%$ increase over the previous 10 years. The Federal Action on Opioids initiative has reported that "the opioid crisis can be linked to the rapid rise in rates of drug overdoses and death involving both: prescription opioids; and increasingly toxic illegal drugs due to the increased presence of powerful illegal substances, such as fentanyl, a drug 50-100 times more potent than morphine." ${ }^{5}$ The Canadian government also reported that there were 3286 apparent opioid- 
related deaths in Canada in 2018, of which 93\% were accidental (unintentional). ${ }^{16}$ In response to this crisis, the government has put into place a national Consultation on the Canadian Drugs and Substances Strategy. ${ }^{17}$

In 2007 , Baldisseri reported that $10 \%$ to $15 \%$ of health care professionals misuse drugs (including opioids [1.1\%] and tranquilizers [2.3\%]) or alcohol during their lifetime, a rate similar to that observed in the general population. ${ }^{18}$ These professionals, who are exposed to controlled substances in the course of their work, are at risk of contributing to the problem of diversion. ${ }^{19}$ The extent of substance diversion in the hospital setting is unknown and difficult to quantify. Health care professionals have privileged access to controlled substances, and problems related to overprescribing, misuse, and diversion may contribute to adverse events, omission of doses for patients, and other unintended consequences. ${ }^{19,20}$ In response to current legal obligations, the risks of diversion and abuse, and the opioid crisis, the Quebec Ministry of Health and Social Services issued a warning to hospital directors about the risk of theft of narcotics in hospitals (Lafleur P, "Vigilance accrue pour les narcotiques" letter sent by e-mail to presidents and directors general of public health care and social services establishments, July 9, 2018). Given the enteral and parenteral use of controlled substances in hospitals and the pivotal role played by hospital pharmacists in the proper use of these substances, we were interested in compliance with recommended practices for controlled substances in our health care facility.

The primary objectives of this descriptive cross-sectional study were to determine compliance of the study hospital with recommended practices for the management of controlled substances and to identify potential actions to improve compliance. The secondary objective was to identify the steps of the drug pathway for controlled substances in the hospital setting and associated failure modes within the study hospital.

\section{METHODS}

\section{Practice Setting}

The study was conducted from January to April 2018 at Centre hospitalier universitaire Sainte-Justine, a 500-bed motherchild academic hospital located in Montréal, Quebec. At this facility, every drug prescription is validated by a pharmacist and is visible to nursing staff within the patient care file or is accessible through a paper or electronic medication administration record (MAR), depending on the hospital department.

\section{Management of Controlled Substances}

The controlled substances listed on the hospital's formulary are distributed in patient care units by means of automated dispensing cabinets (ADCs) $(n=40)$; distribution in ambulatory clinics is recorded in a handwritten controlled substance log. In the operating and delivery rooms, an anesthesia narcotics box holds a standard selection of controlled substances and a controlled substances log, where the anesthesiologist documents the doses administered and destroyed during each working day. The ADCs are interfaced bidirectionally with the pharmacy information system. To obtain a dose from an ADC, the nurse must enter an access code and password or provide biometric identification (fingerprint). The ADCs are replenished by authorized senior pharmacy technicians using barcode readers; the process must be witnessed. Caregivers participate in inventory control through blind counts of doses dispensed by the ADC or witnessed counts (at each shift change) of doses stored in a locked cabinet. Any discrepancy in inventory must be reconciled by the assistant head nurse on the shift. Unresolved discrepancies are subject to joint investigation by the pharmacy department (a senior pharmacy technician and/or pharmacist) and the administrator of the patient care unit.

Controlled substances are generally dispensed in single-dose format. However, a majority of formats usually require additional manipulation by nurses to put the prescribed dose into a syringe or bag. A few products are dispensed in bottles (e.g., morphine and codeine in liquid form for oral administration). The preparation and administration of most controlled substances requires a double check and double signature on the MAR. Some prescriptions of controlled substances are not validated by the pharmacist because they are required on an urgent basis (e.g., in an emergency situation or in an operating or delivery room). Waste and destruction of residual quantities are performed and documented by nursing staff, with all processes being witnessed by another member of the nursing staff.

\section{Compliance Framework}

Before we could assess compliance of the hospital's practices for management of controlled substances, it was necessary to identify a suitable tool for this purpose. We used Google and Google Scholar to search the Internet for relevant tools, using the keywords "controlled substances" and "hospital" and "diversion". After review of all tools identified in the search, we selected a framework produced by the California Hospital Association (CHA). ${ }^{21}$ No equivalent tool reflecting Canadian regulations was found. This framework, first published in 2013 to support hospital self-assessment for secure management of controlled drugs and prevention of their diversion, incorporates 12 themes, 24 key statements, and 113 compliance criteria according to stages of the drug pathway. [Note: The framework has since been updated, but the updated version was not available at the time of our study.]

For each criterion, a research assistant (M.V.) observed practices within the hospital pharmacy, on the patient care units, in outpatient care clinics, and in the operating and delivery rooms, and recorded the level of compliance as compliant, partially compliant, or noncompliant. Because US and Canadian requirements for the management of controlled substances are different, 
practices that were deemed noncompliant with criteria derived from US regulations but compliant with equivalent Canadian regulations were recorded as compliant. Where no equivalence between Canadian and US regulations was found, the criterion was designated as not applicable. The categorization was subsequently validated by the other members of the research team, with disagreements resolved by consensus. Corrective actions were identified for each compliance criterion that was categorized as noncompliant or partially compliant. An action plan and schedule for implementing the corrective actions were also produced.

\section{Ishikawa Diagram}

In addition to assessing the compliance of hospital practices for management of controlled substances, we developed an Ishikawa diagram of steps in the drug pathway for use of controlled substances in hospitals, as well as the associated failure modes at the study hospital. The purpose of the diagram was to identify and better understand weaknesses in the drug pathway that could lead to diversion. This diagram was developed iteratively by a research assistant (M.V.), with validation by the rest of the research team (S.A., M.T., D.L., J.-F.B.).

\section{RESULTS}

The pathway for controlled substances at the study hospital was compliant with 56 (49.6\%) of the 113 CHA criteria, partially compliant with $27(23.9 \%)$ of the criteria, and noncompliant with $24(21.2 \%)$ of the criteria; the remaining 6 criteria $(5.3 \%)$ were not applicable (Table 1). Under Canadian regulations, any unexplained loss of controlled substances must be traced and reported to Health Canada within 10 days, but there is no obligation to report to a board of pharmacy. Similarly, Canada does not have the equivalent of the US Drug Enforcement Administration form 222 for ordering controlled substances. These criteria were therefore considered not applicable in the Canadian context. The practice evaluation highlighted 22 corrective actions, $12(55 \%)$ that could be implemented in the short term, $8(36 \%)$ suitable for implementation in the medium term, and 2 (9\%) suitable for both the short and medium term. These proposed actions included the creation of a subcommittee (under the auspices of the pharmacy and therapeutics committee) to monitor controlled substances, updates of policies and procedures, and development of new audit and training tools.

The Ishikawa diagram (Table 2) highlighted 14 major steps in the management of controlled substances in health care facilities: selection, ordering (procurement), receipt, transport, storage, computerization (e.g., ADCs), prescription, compounding (including validation), dispensing, administration, waste and disposal or destruction (of both unexpired and expired/unusable drugs), equipment, and quality management. Different personnel would be involved at each of these steps. In addition, we identified 57 potential failure modes. Eight of these failure modes related to the prescribing of controlled substances by the physician. Prescribing too many different substances or too many doses at the time of discharge from hospital can lead to a variety of outpatient problems, including overdose, accidental intoxication, and resale. The failure modes related to selection, ordering (procurement), receipt, transport, storage, computerization, pharmaceutical validation, and destruction (of pharmacy stock) would involve primarily pharmacy staff. As such, staff members must ensure that inventory is tracked at all times and that prescribed drugs are appropriate for each patient. Failure modes affecting administration, return, waste, and destruction (e.g., of partial doses not administered) are more likely related to nurses' practice. All of these failure modes can contribute to misuse of controlled substances within the hospital and after patient discharge, including abuse, prolonged use, dependence, overdose, intentional or involuntary intoxication, and diversion.

\section{DISCUSSION}

To our knowledge, this is the first study describing compliance with recommended practices for management of controlled substances in a Canadian health care facility. In 2011, McClure and others ${ }^{22}$ published the results of a survey of 135 pharmacy departments in acute care facilities in the United States to identify diversion-detection practices for controlled substances. They found that $65 \%$ of respondents reported using surveillance cameras directed at the storage areas for controlled substances in the pharmacy, 31\% restricted access to these storage areas, 31\% prohibited personal items (e.g., purses, backpacks) in the storage areas for controlled substances, and $4 \%$ altered drug packaging by deconditioning or marking the label packaging to prevent theft and resale. ${ }^{22}$

We found that practices at the study hospital were fully compliant with about half of the CHA criteria and partially compliant with another quarter of the criteria; however, practices were noncompliant with about $20 \%$ of the criteria. The hospital's pharmacy department has fully satisfied the requirements of the national accreditation body (Accreditation Canada) and the Ordre des pharmaciens du Québec; furthermore, it offers state-of-theart drug management (e.g., single-dose distribution, centralization of preparations, traceability of drug preparation through digitization, narcotic boxes in operating rooms) and technologies (e.g., electronic MARs, ADCs with barcode readers in all care units). Nonetheless, this study has shown that improvements can still be made to optimize the management of controlled substances.

Some of the technologies already being used in the study hospital could contribute to reducing the risk of diversion. ADCs increase the traceability of medication-related activities by allowing confirmation, through user name, password, or biometric features, of anyone involved in replenishing or dispensing drug doses. However, this technology is not flawless, and previous studies have highlighted failure modes associated with this equipment. Dubois and others ${ }^{23}$ assessed risks of diversion associated 
This single copy is for your personal, non-commercial use only.

For permission to reprint multiple copies or to order presentation-ready copies for distribution, contact CJHP at publications@cshp.pharmacy

\section{Table 1 (Part 1 of 2). Profile of Compliance Relating to Management of Controlled Substances in Health Care} Institutions and Corrective Actions

\begin{tabular}{|c|c|c|c|c|c|}
\hline \multirow[t]{2}{*}{ Themes and Key Statements* } & \multicolumn{4}{|c|}{$\begin{array}{l}\text { Level of Compliance } \\
\text { ( } \% \text { of Criteria) }\end{array}$} & \multirow[t]{2}{*}{ Corrective Actions } \\
\hline & $\mathrm{C}$ & PC & NC & NA & \\
\hline $\begin{array}{l}\text { Safety teams / organizational structure } \\
\text { 1. Organization defines CS diversion- } \\
\text { prevention program ( } n=4 \text { criteria) }\end{array}$ & 0 & 50 & 50 & 0 & $\begin{array}{l}\text { Short term } \\
\text { 1. Implement a permanent subcommittee of the } \\
\text { pharmacy and therapeutics committee, } \\
\text { dedicated to CS } \\
\text { Medium term } \\
\text { 2. Develop a formal CS diversion-prevention } \\
\text { program }\end{array}$ \\
\hline $\begin{array}{l}\text { 2. } \text { Organizational structure is in place that } \\
\text { supports an effective CS diversion-prevention } \\
\text { program ( } n=5 \text { criteria) }\end{array}$ & 0 & 80 & 20 & 0 & $\begin{array}{l}\text { Short term } \\
\text { 3. Update relevant policies and procedures } \\
\text { (e.g., contracts, purchase orders, inventory } \\
\text { records, stock replenishment documents) }\end{array}$ \\
\hline $\begin{array}{l}\text { 3. Organization proactively collaborates with } \\
\text { local law enforcement ( } n=1 \text { criterion) }\end{array}$ & 0 & 0 & 100 & 0 & $\begin{array}{l}\text { See corrective action } 2 \text { (develop formal CS } \\
\text { diversion-prevention program) }\end{array}$ \\
\hline $\begin{array}{l}\text { 4. Organization fulfills all reporting requirements } \\
\text { for diversion or loss of CS ( } n=3 \text { criteria) }\end{array}$ & 0 & 33 & 0 & 67 & $\begin{array}{l}\text { Short term } \\
\text { 4. Develop a web page to quickly report } \\
\text { diversion/loss and its management, including } \\
\text { notification to regulatory authority }\end{array}$ \\
\hline $\begin{array}{l}\text { Access to information, accurate reporting, } \\
\text { monitoring, surveillance, detection systems } \\
\text { 5. Organization reviews and audits relevant data } \\
\text { that could indicate potential CS diversion } \\
(n=1 \text { criterion }) \\
\end{array}$ & 100 & 0 & 0 & 0 & None required. \\
\hline $\begin{array}{l}\text { 6. Organization tracks and reviews measures } \\
\text { recommended by medication safety committee } \\
\text { or other designated groups reporting directly } \\
\text { to a medical staff committee ( } n=4 \text { criteria) }\end{array}$ & 50 & 50 & 0 & 0 & $\begin{array}{l}\text { Short term } \\
\text { 5. Develop structured approach involving at least } \\
3 \text { trained pharmacy technicians and } \\
2 \text { pharmacists to periodically and systematically } \\
\text { audit a sample of transactions from the } \\
\text { pharmacy information system, ADCs, and } \\
\text { MARs } \\
\text { 6. Develop a checklist of all key activities of the } \\
\text { CS pharmacy technician to maintain a high } \\
\text { level of awareness }\end{array}$ \\
\hline $\begin{array}{l}\text { Facility expectations } \\
\text { 7. Organization communicates the expectation } \\
\text { that staff "speak up" when they become aware } \\
\text { of an issue related to CS diversion ( } n=2 \text { criteria) }\end{array}$ & 50 & 50 & 0 & 0 & $\begin{array}{l}\text { Medium term } \\
\text { 7. Hold an annual event on CS use and misuse to } \\
\text { increase awareness of ethical obligations of all } \\
\text { stakeholders and establish an anonymous } \\
\text { reporting process }\end{array}$ \\
\hline $\begin{array}{ll}8 . & \text { Organization establishes full disclosure policy } \\
(n=1 \text { criterion })\end{array}$ & 100 & 0 & 0 & 0 & None required. \\
\hline $\begin{array}{l}\text { 9. Organization's staffing practices support an } \\
\text { effective organization-wide CS diversion- } \\
\text { prevention program ( } n=6 \text { criteria) }\end{array}$ & 33 & 17 & 50 & 0 & $\begin{array}{l}\text { Short term } \\
\text { 8. Develop a dedicated page on the hospital } \\
\text { intranet for all key messages, documents, and } \\
\text { tools regarding CS } \\
\text { 9. Review the register for paper and electronic } \\
\text { signatures of prescribers }\end{array}$ \\
\hline $\begin{array}{l}\text { 10. Organization does not allow sharing of pass } \\
\text { codes ( } n=1 \text { criterion) }\end{array}$ & 100 & 0 & 0 & 0 & None required. \\
\hline $\begin{array}{l}\text { Education of staff (and patients) } \\
\text { 11. Organization has in place an effective and } \\
\text { comprehensive training and education program } \\
\text { for all staff on CS diversion prevention } \\
\text { ( } n=7 \text { criteria) }\end{array}$ & 14 & 43 & 43 & 0 & $\begin{array}{l}\text { Medium term } \\
\text { 10. Develop an e-learning program for nursing } \\
\text { and medical students and residents } \\
\text { 11. Develop a CS committee within the regulatory } \\
\text { authority and in key pharmacy associations to } \\
\text { share good practices and challenges }\end{array}$ \\
\hline $\begin{array}{l}\text { Storage and security } \\
\text { 12. Organization stores CS and other high-risk } \\
\text { items securely, in all settings and circumstances } \\
\text { ( } n=1 \text { criterion) }\end{array}$ & 100 & 0 & 0 & 0 & None required. \\
\hline $\begin{array}{l}\text { 13. Organization has process in place for } \\
\text { securing CS ( } n=13 \text { criteria) }\end{array}$ & 69 & 8 & 23 & 0 & $\begin{array}{l}\text { Short term } \\
\text { 12. Include in the revised policies and procedures } \\
\text { information about patients' own CS } \\
\text { (e.g., cannabis oil) }\end{array}$ \\
\hline
\end{tabular}


This single copy is for your personal, non-commercial use only.

For permission to reprint multiple copies or to order presentation-ready copies for distribution, contact CJHP at publications@cshp.pharmacy

\section{Table 1 (Part 2 of 2). Profile of Compliance Relating to Management of Controlled Substances in Health Care Institutions and Corrective Actions}

\begin{tabular}{|c|c|c|c|c|c|}
\hline \multirow[t]{2}{*}{ Themes and Key Statements* } & \multicolumn{4}{|c|}{$\begin{array}{l}\text { Level of Compliance } \\
\text { (\% of Criteria) }\end{array}$} & \multirow[t]{2}{*}{ Corrective Actions } \\
\hline & C & PC & NC & NA & \\
\hline $\begin{array}{l}\text { 14. Organization uses camera surveillance in } \\
\text { high-risk areas as appropriate ( } n=1 \text { criterion) }\end{array}$ & 100 & 0 & 0 & 0 & $\begin{array}{l}\text { Medium term } \\
\text { 13. Add camera surveillance in key areas of } \\
\text { patient care wards, operating room, and } \\
\text { emergency department }\end{array}$ \\
\hline $\begin{array}{l}\text { Procurement } \\
\text { 15. Organization effectively and safely handles } \\
\text { procurement in the hospital pharmacy } \\
\text { ( } n=10 \text { criteria) }\end{array}$ & 60 & 0 & 0 & 40 & $\begin{array}{l}\text { Medium term } \\
\text { 14. Provide additional ADCs for ambulatory clinics } \\
\text { for CS management }\end{array}$ \\
\hline $\begin{array}{l}\text { Prescribing } \\
\text { 16. Organization's ordering and prescribing } \\
\text { practices minimize the risk of CS diversion } \\
(n=5 \text { criteria) }\end{array}$ & 60 & 40 & 0 & 0 & $\begin{array}{l}\text { Short and medium term } \\
\text { 15. Periodically review preprinted orders to optimize } \\
\text { CS prescribing } \\
\text { 16. Conduct periodic spot audits in operating } \\
\text { and delivery rooms }\end{array}$ \\
\hline $\begin{array}{l}\text { Preparation and dispensing } \\
\text { 17. Organization's preparation and dispensing } \\
\text { practices minimize the risk of CS diversion } \\
\text { ( } n=12 \text { criteria) }\end{array}$ & 33 & 50 & 17 & 0 & $\begin{array}{l}\text { Short term } \\
\text { 17. Purchase secure transport box for stock } \\
\text { replenishment by technical staff }\end{array}$ \\
\hline $\begin{array}{l}\text { Administration } \\
\text { 18. Organization's CS administration practices } \\
\text { minimize the risk of CS diversion ( } n=6 \text { criteria) }\end{array}$ & 83 & 0 & 17 & 0 & $\begin{array}{l}\text { See corrective action } 3 \text { (update relevant policies } \\
\text { and procedures [e.g., contracts, purchase orders, } \\
\text { inventory records, stock replenishment documents]) }\end{array}$ \\
\hline $\begin{array}{l}\text { Handling of waste } \\
\text { 19. Organization's "waste" handling practices } \\
\text { maintain chain of custody, to minimize the } \\
\text { risk of CS diversion ( } n=6 \text { criteria) }\end{array}$ & 50 & 0 & 50 & 0 & $\begin{array}{l}\text { Short term } \\
\text { 18. Conduct periodic spot audits for waste and } \\
\text { returns } \\
\text { Medium term } \\
\text { 19. Purchase a Raman spectrophotometer for } \\
\text { CS identification }\end{array}$ \\
\hline $\begin{array}{l}\text { 20. Organization's practices for handling } \\
\text { unused CS, empty CS containers, and CS } \\
\text { returned to pharmacy minimize the risk of } \\
\text { diversion ( } n=10 \text { criteria) }\end{array}$ & 80 & 10 & 10 & 0 & $\begin{array}{l}\text { Short term } \\
\text { 20. Include in the revised policies and procedures } \\
\text { information about drug returns }\end{array}$ \\
\hline $\begin{array}{l}\text { Monitoring of CS and process if diversion } \\
\text { is suspected } \\
\text { 21. Organization removes access to CS if diversion } \\
\text { is suspected ( } n=2 \text { criteria) }\end{array}$ & 100 & 0 & 0 & 0 & None required. \\
\hline $\begin{array}{l}\text { 22. Organization regularly monitors CS through } \\
\text { inventory, reports, and audits ( } n=9 \text { criteria) }\end{array}$ & 22 & 33 & 45 & 0 & $\begin{array}{l}\text { Medium term } \\
\text { 21. Develop a structured report to support } \\
\text { interhospital comparisons (e.g., DDD, oral } \\
\text { morphine equivalent dose) }\end{array}$ \\
\hline $\begin{array}{l}\text { 23. Process is in place to resolve CS discrepancies } \\
(n=2 \text { criteria) }\end{array}$ & 100 & 0 & 0 & 0 & $\begin{array}{l}\text { Short term } \\
\text { 22. Develop a video for nursing staff }\end{array}$ \\
\hline $\begin{array}{l}\text { 24. Organization has a standard process to } \\
\text { investigate cases of potential diversion } \\
\text { ( } n=1 \text { criterion) }\end{array}$ & 100 & 0 & 0 & 0 & None required. \\
\hline Overall no. $(\%)(n=113)$ & $56(49.6)$ & $27(23.9$ & $4(21.2)$ & $6(5.3)$ & \\
\hline
\end{tabular}

with ADCs and identified 27 failure modes specific to this type of equipment, with a $1.2 \%$ inventory discrepancy for movement of controlled substances in 19 cabinets over a 5-month period. Elsewhere, Crowson and Monk-Tutor ${ }^{24}$ demonstrated that the number of individuals likely to divert controlled substances from decentralized ADCs was 1.12 per 100 beds. More recently, a medical resident at the Montreal Children's Hospital (in the same city as the setting for the current study) was arrested in possession of several vials of fentanyl that he had diverted from operating room carts. ${ }^{25}$ Although most health care facilities in Canada now use ADCs, this single technological measure is insufficient to detect and eliminate diversions. Some authors have described additional tools for comparing prescriptions with doses dispensed and actually administered. ${ }^{26,27}$ Without these audit tools, it is possible to bypass the ADCs.

Several factors may have contributed to the noncompliance observed in our study. Canadian regulations differ from US regulations in various aspects (e.g., in Canada, organizations are prevented by law from having a "for cause" policy for drug testing). The comparison of practices at the study hospital against 
Table 2 (Part 1 of 2). Ishikawa Diagram of the 14 Steps in the Drug Pathway for Controlled Substances in Health Care Facilities and Associated Failure Modes

Step of Drug Pathway for CS

Failure Modes for CS

\begin{tabular}{|c|c|c|c|}
\hline & Selection on a hospital formulary & & $\begin{array}{l}\text { Suboptimal product selected } \\
\text { Suboptimal concentration selected } \\
\text { Inappropriate format selected }\end{array}$ \\
\hline 2. & Procurement & $\begin{array}{l}4 . \\
5 . \\
6 .\end{array}$ & $\begin{array}{l}\text { Unauthorized order sent to a drug manufacturer } \\
\text { or wholesaler } \\
\text { Wrong product ordered } \\
\text { Wrong quantity ordered }\end{array}$ \\
\hline 3. & Receipt & $\begin{array}{l}7 . \\
8 . \\
9 . \\
10 . \\
11 . \\
12 . \\
13 .\end{array}$ & $\begin{array}{l}\text { Loss of packing slip or bill } \\
\text { Wrong product selected for data entry } \\
\text { Wrong quantity selected for data entry } \\
\text { Wrong storage location used } \\
\text { CS product replaced by a faked alternative } \\
\text { CS quantity confirmed on drug procurement software, } \\
\text { but drug diverted/stolen } \\
\text { Data for CS quantity not entered in drug procurement } \\
\text { software and drug diverted/stolen }\end{array}$ \\
\hline$\overline{4 .}$ & Transport & $\begin{array}{l}14 . \\
15 .\end{array}$ & $\begin{array}{l}\text { Product stolen before arrival at final destination } \\
\text { Sharing by authorized staff of access codes for } \\
\text { pneumatic tubing }\end{array}$ \\
\hline 5. & Storage in pharmacy department & $\begin{array}{l}16 . \\
17 . \\
18 . \\
19 .\end{array}$ & $\begin{array}{l}\text { Unauthorized individuals having access to storage area } \\
\text { Product stored at wrong location } \\
\text { Product replaced by a faked alternative } \\
\text { Product stolen }\end{array}$ \\
\hline & $\begin{array}{l}\text { Replenishment of automated dispensing } \\
\text { cabinets or locked narcotics box }\end{array}$ & $\begin{array}{l}20 . \\
21 . \\
22 .\end{array}$ & $\begin{array}{l}\text { Wrong product replenished } \\
\text { Wrong quantity entered } \\
\text { Product stolen during replenishment process }\end{array}$ \\
\hline 7. & Prescribing & $\begin{array}{l}23 . \\
24 . \\
25 . \\
26 . \\
27 . \\
28 . \\
29 . \\
30 .\end{array}$ & $\begin{array}{l}\text { Prescribing of a CS product by unauthorized staff } \\
\text { Suboptimal product prescribed } \\
\text { Suboptimal concentration prescribed } \\
\text { Suboptimal format prescribed } \\
\text { Suboptimal quantity prescribed } \\
\text { Suboptimal dose prescribed } \\
\text { Faked order } \\
\text { Modified order }\end{array}$ \\
\hline 8. & $\begin{array}{l}\text { Compounding, validation, and dispensing } \\
\text { (central pharmacy) }\end{array}$ & $\begin{array}{l}31 . \\
32 . \\
33 . \\
34 . \\
35 .\end{array}$ & $\begin{array}{l}\text { Wrong product entered, validated, and dispensed } \\
\text { Wrong concentration entered, validated, and dispensed } \\
\text { Wrong format entered, validated, and dispensed } \\
\text { Wrong quantity entered, validated, and dispensed } \\
\text { Wrong dose entered, validated, and dispensed }\end{array}$ \\
\hline & Dispensing from ward stock & $\begin{array}{l}36 . \\
37 . \\
38 .\end{array}$ & $\begin{array}{l}\text { Sharing of ADC keys or passwords by authorized staff } \\
\text { Ampoule of CS reported as being broken while it is } \\
\text { diverted } \\
C S \text { dose dispensed from ADC is not administered } \\
\text { to the patient }\end{array}$ \\
\hline$\overline{10 .}$ & Administration & $\begin{array}{l}39 . \\
40 .\end{array}$ & $\begin{array}{l}\text { CS dose dispensed from ADC is registered in the MAR } \\
\text { but is not administered to the patient } \\
\text { A fraction of the dispensed dose of a prescribed CS is } \\
\text { not administered to the patient, and the residual amount } \\
\text { is diverted } \\
\text { Fake patient created in ADC interface to justify illegal } \\
\text { dispensing of CS dose }\end{array}$ \\
\hline & $\begin{array}{l}\text { Waste and disposal of unexpired or } \\
\text { residual amount }\end{array}$ & $\begin{array}{l}42 . \\
43 . \\
44 . \\
45 . \\
46 .\end{array}$ & $\begin{array}{l}\text { Content of a dispensed CS is replaced by an alternative } \\
\text { product and is returned to the ADC } \\
\text { Unused amount of CS not returned properly to ADC } \\
\text { Unused amount of CS not returned properly to ADC } \\
\text { but registered in the software as being returned } \\
\text { Unused amount of CS not destroyed properly } \\
\text { (with a witness) } \\
\text { Unused amount of CS replaced by an alternative for } \\
\text { diversion }\end{array}$ \\
\hline
\end{tabular}




\section{Table 2 (Part 2 of 2). Ishikawa Diagram of the 14 Steps in the Drug Pathway for Controlled Substances in Health Care Facilities and Associated Failure Modes}

Step of Drug Pathway for CS

12. Waste and disposal of expired or unusable amount
Failure Modes for CS

47. Expired or unusable CS replaced by an alternative product and replaced in stock for reuse

48. Expired or unusable CS not destroyed properly and replaced in stock for reuse

49. Expired or unusable CS stolen from residual amount in patient care areas

50. Expired or unusable CS stolen after signature of a witness to confirm destruction or with complacent witness

51. Unsafe waste container used to dispose of residual CS amount

\begin{tabular}{lll}
\hline 13. Defective equipment (any stage of pathway) & 52. & Defective pocket in ADC remains unrepaired \\
& 53. CS stocked in open-matrix drawer \\
\hline 14. Quality management and investigation & 54. CS discrepancies remain unresolved \\
& 55. Absence or postponement of control audits \\
& 56. (e.g., periodic audits omitted) \\
& 57. Suspected diversion is underreported \\
\hline
\end{tabular}

$\overline{\mathrm{ADC}}=$ automated dispensing cabinet, $\mathrm{CS}=$ controlled substance, $\mathrm{MAR}=$ medication administration record a US framework is therefore imperfect. Although legislation and regulations governing controlled substances exist in Canada, the relevant federal department (Health Canada) has not published an explicit and comprehensive guide to these substances since $1990,{ }^{28}$ with the exception of an information document for hospitals concerning benzodiazepines and targeted substances, which first appeared in $1998 .{ }^{29}$ In Quebec, the Ordre des pharmaciens du Québec has published a selection of its standards of practice to clarify certain terms and conditions related to controlled substances. ${ }^{30-33}$ Furthermore, pharmacy management teams are subject to dozens of standards and thousands of compliance criteria, which is challenging for practitioners. ${ }^{34}$ Thus, it would be desirable for Health Canada to publish an updated guide covering all legal requirements for the management of controlled substances. In addition, because pharmacy practice falls under provincial jurisdiction, each provincial college of pharmacy must play a role in the application of such a guide. External audits can help to improve practices, and Health Canada has recently resumed its program of large-scale inspection of community pharmacies and pharmacy departments of health care facilities. ${ }^{35}$ The various organizations responsible for auditing the drug pathway should work together, using the same audit tool, to ensure agreement on standards and criteria and to channel efforts for the proper use of controlled substances.

Our study highlights 22 corrective actions that could be implemented in the short or medium term. The establishment of a subcommittee for the management of controlled substances, under the auspices of the pharmacy and therapeutics committee, would be a cornerstone for mobilizing physicians, nurses, pharmacists, and risk management counsellors to support implementation of these corrective actions. The pharmacy and therapeutics committee must also ensure proper use and monitoring of controlled substances, through an approach similar to antimicrobial stewardship. Such measures are already in place in the United States, where (since January 1, 2018), hospitals must meet new, revised pain assessment and management standards as a requirement for accreditation by the Joint Commission. ${ }^{36}$ The evaluation and improvement of prescribing practices by practitioners is essential to reducing misuse.

In Canada, under the Joint Statement of Action to Address the Opioid Crisis, the Canadian Society of Hospital Pharmacists (CSHP) and other organizations have committed "to work within their respective areas of responsibility to improve prevention, treatment, harm reduction and enforcement associated with problematic opioid use through timely, concrete actions that deliver clear results." ${ }^{37}$ On August 1, 2018, CSHP released for consultation its guidelines on secure management and prevention of diversion of controlled drugs and substances in hospitals and health care facilities, and the approved guidelines were published in early 2019. ${ }^{38}$ These guidelines are meant to replace Health Canada's outdated 1990 guide, and they incorporate all elements appearing in the CHA framework that was used for the current study. Similar guidelines have been published by the American Society of Health-System Pharmacists. ${ }^{39}$ It is hoped that CSHP will also develop a self-assessment tool to facilitate the use of its guidelines.

This descriptive study has provided a detailed and practical description of the risks of diversion of controlled substances in one Canadian health care facility. Although it is reasonable to assume that practices at the study hospital, an academic motherchild facility, are representative of those in other institutions, the results cannot be fully generalized to all Canadian health care facilities. Furthermore, the results of this study cannot be used to quantify the rate of diversion of controlled substances. Nonetheless, the study does describe surveillance measures in place and potential corrective actions, albeit according to a US 
This single copy is for your personal, non-commercial use only.

For permission to reprint multiple copies or to order presentation-ready copies for distribution, contact CJHP at publications@cshp.pharmacy

standard. These results can be used as a starting point for future comparative analyses.

\section{CONCLUSION}

In this study, the pathway for controlled substances at the study hospital was compliant with nearly half of the criteria in a pre-existing framework, and 22 corrective actions were identified to further improve compliance. Pharmacists, physicians, and nurses should be mobilized to optimize the use of controlled substances throughout the drug-use process.

\section{References}

1. A propos de CanLII / About CanLII. Ottawa (ON): Institut canadien d'information juridique; [cited 2019 Feb 10]. Available from: https:// www.canlii.org/fr/info/a_propos.html

2. Convention sur les substances psychotropes, 1971 / Convention on psychotropic substances, 1971. New York (NY): Office des Nations Unies contre la drogue et le crime; 1971 [cited 2018 Sep 21]. Available from: https:// www.unodc.org/unodc/fr/treaties/psychotropics.html

3. Loi réglementant certaines drogues et autres substances, L.C. 1996, ch. 19 / Controlled Drugs and Substances Act, S.C. 1996, c. 19. Available from: http://laws-lois.justice.gc.ca/fra/lois/c-38.8/ [cited 2018 Sep 21].

4. Règlement sur les stupéfiants, C.R.C. ch. 1041 / Narcotic Control Regulations, C.R.C., c. 1041. Available from: http://laws-lois.justice.gc.ca/fra/ reglements/C.R.C.,_ch._1041/index.html [cited 2018 Sep 21].

5. Règlement sur les benzodiazépines et autres substances ciblées, DORS/2000-217 I Benzodiazepines and Other Targeted Substances Regulations, SOR/ 2000-217. Available from: http://laws-lois.justice.gc.ca/fra/reglements/ DORS-2000-217/index.html [cited 2018 Sep 21]

6. Règlement sur les précurseurs, DORS/2002-359 / Precursor Control Regulations, SOR/2002-359. Available from: http://laws-lois.justice.gc.ca/ fra/reglements/DORS-2002-359/index.html [cited 2018 Sep 21].

7. Standards de pratique. Montréal (QC): Ordre des pharmaciens du Québec; 2016 [cited 2018 Sep 21]. Available from: https://www.opq.org/fr-CA/ publications/standards-de-pratique/

8. Smith SM, Dart RC, Katz NP, Paillard F, Adams EH, Comer SD, et al. Classification and definition of misuse, abuse, and related events in clinical trials: ACTTION systematic review and recommendations. Pain. 2013; $154: 2287-96$

9. Gomes T, Mamdani MM, Paterson JM, Dhalla IA, Juurlink DN. Trends in high-dose opioid prescribing in Canada. Can Fam Physician. 2014;60(9): 826-32.

10. Lynch ME, Fischer B. Prescription opioid abuse: what is the real problem and how do we fix it? Can Fam Physician. 2011;57(11):1241-2, e403-5.

11. United Nations population data. Opioid consumption maps - morphine, mg/capita, 2015. Vienna (Austria): International Narcotics Control Board; [cited 2019 Feb 10]. Available from: https://ppsg.medicine.wisc.edu/

12. Responding to Canada's opioid crisis. Ottawa (ON): Government of Canada; 2018 Sep 9 [cited 2018 Sep 21]. Available from: https://www. canada.ca/en/health-canada/services/substance-use/problematic-prescriptiondrug-use/opioids/responding-canada-opioid-crisis.html

13. Pan-Canadian trends in the prescribing of opioids and benzodiazepines, 2012 to 2017. Ottawa (ON): Canadian Institute for Health Information; 2018 [cited 2018 Sep 21]. Available from: https://www.cihi.ca/sites/default/ files/document/opioid-prescribing-june2018-en-web.pdf

14. O'Connor S, Grywacheski V, Louie K. At-a-glance - hospitalizations and emergency department visits due to opioid poisoning in Canada. Health Promot Chronic Dis Prev Can. 2018;38(6):244-7. DOI: https://doi.org/ 10.24095/hpcdp.38.6.04

15. Federal action on opioids. Ottawa (ON): Government of Canada; 2018 Aug 13 [cited 2018 Sep 21]. Available from: https://www.canada.ca/en/healthcanada/services/substance-use/problematic-prescription-drug-use/opioids/ federal-actions.html
16. National report: apparent opioid-related deaths. Ottawa (ON): Government of Canada; 2019 Apr [cited 2019 May 18]. Available from: https:// www.canada.ca/en/health-canada/services/substance-use/problematicprescription-drug-use/opioids/apparent-opioid-related-deaths.html

17. Responding to Canada's opioid crisis. Ottawa (ON): Government of Canada; [cited 2019 Feb 10]. Available from: https://www.canada.ca/en/healthcanada/services/substance-use/problematic-prescription-drug-use/opioids/ responding-canada-opioid-crisis.html

18. Baldisseri MR. Impaired healthcare professional. Crit Care Med. 2007;35 (2 Suppl):S106-16.

19. Berge KH, Dillon KR, Sikkink KM, Taylor TK, Lanier WL. Diversion of drugs within health care facilities, a multiple-victim crime: patterns of diversion, scope, consequences, detection, and prevention. Mayo Clin Proc. 2012;87(7):674-82.

20. Heroin-addicted technician Kristen Diane Parker infected 3 dozen with hepatitis C. Daily News. 2010 Jan 18 [cited 2018 Sep 21]. Available from http://www.nydailynews.com/news/national/heroin-addicted-techniciankristen-diane-parker-infected-3-dozen-hepatitis-article-1.459165

21. Reducing controlled substances diversion in hospitals. Sacramento (CA): California Hospital Association Medication Safety Committee; 2013 [cited 2019 May 18]. Available from: https://www.chpso.org/sites/main/files/ file-attachments/controlled_substance_diversion.pdf

22. McClure SR, O’Neal BC, Grauer D, Couldry RJ, King AR. Compliance with recommendations for prevention and detection of controlled-substance diversion in hospitals. Am J Health Syst Pharm. 2011;68(8):689-94.

23. Dubois S, Bernier E, Rivard J, Yu L, Atkinson S, Bussières JF. Utilisation optimale des cabinets automatisés décentralisés : le point sur les risques de détournement des substances désignées. Can J Hosp Pharm. 2017;70(2):120-6.

24. Crowson K, Monk-Tutor M. Use of automated controlled substance cabinets for detection of diversion in US hospitals: a national study. Hosp Pharm. 2005;40(11):977-83.

25. Un médecin de l'Hôpital de Montréal pour enfants accusé de vol de fentanyl. Radio-Canada; 2018 Mar 7 [cited 2018 Sep 21]. Available from: https://ici.radio-canada.ca/nouvelle/1087880/medecin-hopital-montrealpour-enfants-accuse-vol-fentanyl

26. Epstein RH, Dexter F, Gratch DM, Perino M, Magrann J. Controlled substance reconciliation accuracy improvement using near real-time drug transaction capture from automated dispensing cabinets. Anesth Analg. 2016; 122(6):1841-55

27. Brenn BR, Kim MA, Hilmas E. Development of a computerized monitoring program to identify narcotic diversion in a pediatric anesthesia practice. $A m$ J Health Syst Pharm. 2015;72(16):1365-72.

28. Bureau of Dangerous Drugs; Canadian Hospital Association; Canadian Nurses Association; Canadian Society of Hospital Pharmacists. Guidelines for the secure distribution of narcotic and controlled drugs in hospitals. Ottawa (ON): Minister of Supply and Services Canada; 1990 Jan [cited 2018 Sep 21]. Available from: https://scp.inltouch.org/document/3631/ REF_Narcotic_Secure_Dist_in_Hsptl_19900101.pdf

29. Document d'information à l'intention des hôpitaux. Reglements sur les benzodiazépines et autres substances ciblées. Ottawa (ON): Health Canada, Bureau of Dangerous Drugs; 2000 Aug 29 [cited 2018 Sep 21]. Available from: https://www.canada.ca/content/dam/hc-sc/migration/hc-sc/hc-ps/alt_ formats/hecs-sesc/pdf/pubs/precurs/hospitals-guide-hopitaux/00_ 102842_814_hospitals-fra.pdf

30. Stupéfiants, drogues contrôlées et substances ciblées. In: Guide d'application des standards de pratique : Gestion des médicaments. Montréal (QC): Ordre des pharmaciens du Québec; 2016 [cited 2018 Sep 26] Available from: http://guide.standards.opq.org/guides/stupefiants-drogues-controlees-etsubstances-ciblees-stupefiants-drogues-controlees-et-substances-ciblees

31. Transfert des ordonnances de substances ciblées et de benzodiazépines. Bull Inform Prof [Ordre des pharmaciens du Québec]. 2007;160.

32. Gestion des stupéfiants et des drogues contrôlées en pharmacie communautaire. Bull Inform Prof [Ordre des pharmaciens du Québec]. 2005;152.

33. Votre ordonnance, sa dépendance? Labus de médicaments chez les adolescents, une réalité qui fauche des vies. Linteraction [Ordre des pharmaciens du Québec]. 2014;3(4):6-10. Available from: https://www. opq.org/doc/media/1846_38_fr-ca_0_dm_1181_opq_interaction_ vol3_no4_final.pdf 
This single copy is for your personal, non-commercial use only.

For permission to reprint multiple copies or to order presentation-ready copies for distribution, contact CJHP at publications@cshp.pharmacy

34. Chabrier A, Atkinson S, Lebel D, Bussières JF. Explosion du cadre normatif entourant l'exercice de la pharmacie et le bon usage des médicaments [abstract]. 8th conference of the Réseau Québécois de recherche sur les médicaments; 2018 Oct 19-20; Montréal (QC).

35. Destruction des stupéfiants, drogues contrôlées et substances ciblées : autorisation non requise par Santé Canada. Montréal (QC): Ordre des pharmaciens du Québec; 2016 Jul 19 [cited 2018 Sep 26]. Available from: https://www.opq.org/cms/Media/2549_38_fr-CA_0_interaction_express_ 19072016 destruction med.htm

36. Joint Commission enhances pain assessment and management requirements for accredited hospitals. Perspectives. 2017;37(7):1-4. Available from: https://www.jointcommission.org/assets/1/18/Joint_Commission_ Enhances_Pain_Assessment_and_Management_Requirements_for_ Accredited_Hospitals1.PDF

37. The joint statement of action to address the opioids crisis in Canada: a collective response. Annual report 2016-2017. Ottawa (ON): Canadian Centre on Substance Use and Addiction; 2017 [cited 2018 Sep 21]. Available from: https://www.ccsa.ca/sites/default/files/2019-04/CCSA-Joint-Statement-ofAction-Opioid-Crisis-Annual-Report-2017-en.pdf

38. Controlled drugs and substances in hospitals and healthcare facilities: guidelines on secure management and diversion prevention. Ottawa (ON): Canadian Society of Hospital Pharmacists; 2019 [cited 2019 May 14]. Available from: https://www.cshp.ca/guidelines

39. Brummond PW, Chen DF, Churchill WW, Clark JS, Dillon KR, Dumitru $\mathrm{D}$, et al. ASHP guidelines on preventing diversion of controlled substances. Am J Health Syst Pharm. 2017;74(5):325-48.
Manon Videau is a Research Assistant in the Research Unit in Pharmaceutical Practice, Centre hospitalier universitaire Sainte-Justine, Montréal, Quebec.

Suzanne Atkinson, BPharm, MSc, is Assistant Director of the Pharmacy Department and the Research Unit in Pharmaceutical Practice, Centre hospitalier universitaire Sainte-Justine, Montréal, Quebec.

Maxime Thibault, BPharm, MSc, is a Pharmacist in the Department of Pharmacy and the Research Unit in Pharmaceutical Practice, Centre hospitalier universitaire Sainte-Justine, Montréal, Quebec.

Denis Lebel, BPharm, MSc, is Assistant Director of the Pharmacy Department and the Research Unit in Pharmaceutical Practice, Centre hospitalier universitaire Sainte-Justine, Montréal, Quebec.

Jean-François Bussières, BPharm, MSC, MBA, FCSHP, FOPQ, is Director of the Pharmacy Department and the Research Unit in Pharmaceutical Practice, Centre hospitalier universitaire Sainte-Justine, and is a Clinica Professor in the Faculté de pharmacie, Université de Montréal, Montréal Quebec.

\section{Competing interests: None declared.}

\section{Address correspondence to:}

Jean-François Bussières

Pharmacy Department

Centre hospitalier universitaire Sainte-Justine

3175, chemin de la Côte Sainte-Catherine Montréal QC H3T 1C5

e-mail: jf.bussieres.hsj@ssss.gouv.qc.ca

Funding: None received.

Acknowledgement: The authors would like to thank Peggy Robinson for assistance, in advance of submission, with the English-language presentation.

\section{BEST..is better}

\section{One resource for all types of compounding by pharmacies}

\section{WHAT'S INSIDE?}

- Information for pharmacists, pharmacy technicians, planners, architects, engineers-and others who are involved in decisions or activities that affect compounding

- Guidelines for aseptic compounding, non-aseptic compounding, and compounding which involves hazardous drugs-including radiopharmaceuticals

- Best and leading guidelines on topics such as training. planning and designing the physical environment, developing an air quality strategy, cleaning and decontaminating areas, monitoring the environment, garbing and hand hygiene, developing compounding procedures, documenting, and much more-all in only 230 pages

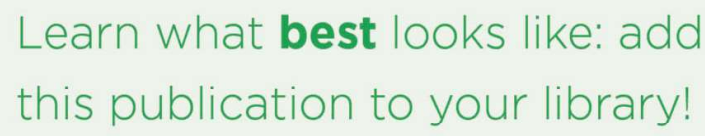
this publication to your library!
HAVE A SNEAK PEEK OR ORDER AT:

https://cshp.ca/compounding-guidelines-pharmacies CSHP MEMBERS PAY A DISCOUNTED PRICE
Canadian Society of Hospital Pharmacists
Société canadienne des pharmaciens d'hôpitaux 